\title{
QUANTIFYING DENITRIFICATION ON A FIELD SCALE IN HUMMOCKY TERRAIN
}

\author{
J.A. ELLIOTT and E. DE JONG \\ Soil Science Department, University of Saskatchewan, Saskatoon, SK.
}

\begin{abstract}
Down-slope and cross-slope curvature and elevation were used to identify nine landscape elements for a slough-focussed basin in hummocky terrain near Hafford, Saskatchewan. Denitrification was measured at monthly intervals from April to October in 1986,1987 and 1988 . The measured values were interpolated to daily values using a simple soil moisture budget and a regression model relating denitrification to moisture content and air temperature. The model predicted denitrification well except in 1987, the fallow year, when the denitrification flush due to substrate availability was underestimated. Annual denitrification was higher in 1987 than in either 1986 or 1988 when wheat and canola, respectively, were grown. Low-lying and convergent elements had greater denitrification than diverging elements or those higher in the landscape. The relative abundance of the landscape elements was used to extend the denitrification predicted for the landscape elements to the whole field.
\end{abstract}

\section{INTRODUCTION}

In hummocky terrain soil properties vary according to their position in the landscape. Soil properties in hummocky landscapes are very variable and field average values are difficult to obtain. Moisture, soil temperature, depth of A horizon and aeration have been shown to vary with position in the landscape (Kachanoski et al. 1985, Macyk et al. 1978, Pennock et al. 1987, de Jong 1981) and since these are all properties which have been shown to affect denitrification, denitrification must also vary.

Ruhe (1960) characterized landscapes based on down-slope curvature. This classification has been widely used but fails to fully characterize the slope as it ignores the effect of cross-slope shape. Pennock et al. (1987) used down-slope and cross-slope curvature to classify landscape elements and were able to characterize variation in the depth of A horizon.

Denitrification rates as high as $100 \mathrm{~kg} / \mathrm{ha} / \mathrm{yr}$ have been observed on level terrain in the Black soil zone (Kirkland and de Jong 1988). Since these losses could be economically significant, it is desirable to characterize denitrification on hummocky terrain so that field averages can be obtained for economic analysis.

Daily measurements of denitrification are not practical and therefore it is necessary to interpolate denitrification rates over the sampling interval. Previous studies (Firestone 1982) have shown denitrification rate to be largely dependant on moisture content and temperature. Several models are available for predicting daily moisture contents (de Jong 1988). One of the simplest of these is the Versatile Soil Moisture Budget (Baier and Robertson 1966) which estimates daily soil moisture on a zone by zone basis using standard meteorological data. The model accounts for evapotranspiration, infiltration, runoff and drainage from a multi-layered soil.

The objective of this paper is to obtain realistic estimates of annual denitrification on a field scale from monthly measurements on landscape elements. 


\section{MATERIALS AND METHODS}

Denitrification and volumetric moisture content were measured at monthly intervals between April and October in 1986, 1987 and 1988 on a site in the Black soil zone near Hafford, Saskatchewan. The soil was classified as a Mayfair loam and the terrain was hummocky with slopes of 10 to $15 \%$. In 1986 wheat was grown on the site, in 1987 the site was fallow and in 1988 canola was grown.

Seven landscape elements were identified in terms of down-slope and cross-slope curvature (see Figure 1) and two level units (one low, one high) were also included. The low level unit was subject to water table influence and the high level unit was not. Sampling took place in a slough-focussed basin on two paired and two single transects radiating from the slough. The sampling sites were arranged so that at least two replicates of every landscape element were sampled. The basin was surveyed on a $5 \mathrm{~m}$ grid and the elevation data was used to calculate the relative abundance of the landscape elements (Table 1). It was assumed that the relative abundances observed in the basin were representative of the whole field.

Table 1. Relative abundance of the landscape elements.

\begin{tabular}{lcc}
\hline \multicolumn{1}{c}{ Element } & Symbol & \% of Land Area \\
\hline Low Level & L & 5 \\
Converging Footslope & C F & 17 \\
Diverging Fotslope & DF & 13 \\
Converging Backslope & C B & 5 \\
Linear Backslope & L B & 3 \\
High Level & L H & 5 \\
Diverging Backslope & D B & 6 \\
Converging Shoulder & C S & 15 \\
Diverging Shoulder & D S & 31 \\
\hline
\end{tabular}

Denitrification was measured using the acetylene inhibition technique of Aulakh (1983) and moisture content was determined volumetrically. Measurements were confined to the surface $25 \mathrm{~cm}$ as this was determined to be the maximum depth at which denitrification occurred. Daily measurements of maximum and minimum temperature and precipitation were obtained from the Environment Canada Meteorological Station at Hafford, Saskatchewan. The Versatile Soil Moisture Budget required moisture contents at saturation, field capacity and permanent wilting point. Field capacity and permanent wilting point were obtained using pressure chambers at pressures of 30 and $1500 \mathrm{kPa}$ respectively (Klute 1986). Saturation moisture content was taken as total porosity measured on soil core samples on the first day of sampling each year.

The moisture budget was used to predict moisture content for three layers (2.5-10 $\mathrm{cm}, 10-17.5 \mathrm{~cm}$ and $17.5-25 \mathrm{~cm}$ ) in the surface $25 \mathrm{~cm}$ of soil. Maximum and minimum temperatures and incident solar radiation were used to predict latent evaporation (Baier and Robertson 1965). This was converted to potential evapotranspiration using a crop factor which depended on the nature of the crop and its growth stage. The amount of crop water extraction was limited to the permanent wilting point. Infiltration and runoff were 
FOOTSLOPE

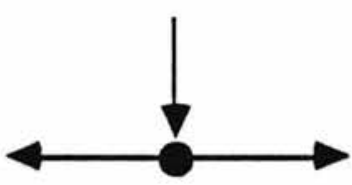

DIVERGING

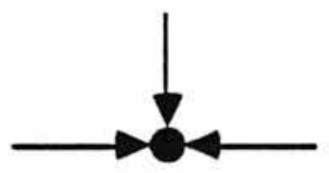

CONVERGING

\section{BACKSLOPE}

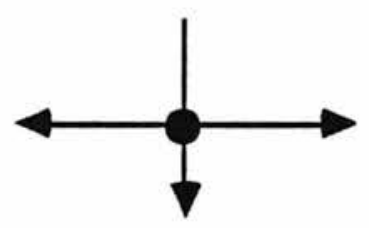

DIVERGING

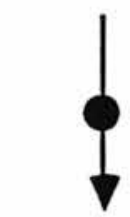

LINEAR

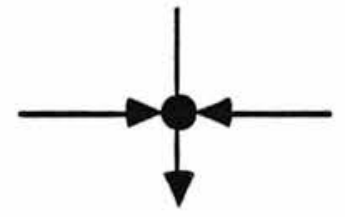

CONVERGING

SHOULER

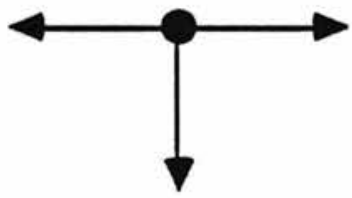

DIVERGING

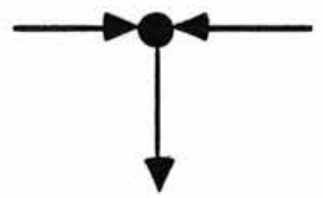

CONVERGING

\section{LEVEL}

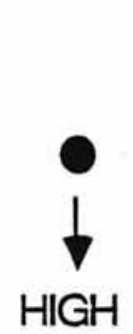

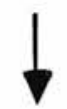

0

LOW

Figure 1. Landscape elements identified by down-slope and cross-slope curvature. The arrows indicate the direction in which water would move. 
calculated using texture and moisture content to find the sorptivity of the soil (Schwab et al. 1966). The soil moisture content was not allowed to exceed the saturation moisture content. Drainage occurred when the soil moisture content was between saturation and field capacity. It was assumed that $75 \%$ of the moisture in excess of field capacity would drain to the next layer in 24 hours. The moisture contents of the three layers were averaged to give a single value for the landscape element.

Simple regression equations to predict daily denitrification from daily soil moisture contents and temperatures were obtained by regressing the actual denitrification measurements against the moisture contents predicted for the sampling day and the actual air temperatures. An equation was obtained for each of the three years in an attempt to account for the different management practises.

The daily predicted denitrification levels on each landscape element were summed to give annual denitrification for the element. Field averages were calculated by using the relative abundance of the landscape elements to obtain a weighted average of annual denitrification.

\section{RESULTS AND DISCUSSION}

A typical prediction of moisture content by the moisture model is shown in Figure 2. The evapotranspiration steadily decreases the moisture content, whilst the infiltration of precipitation and subsequent drainage give rise to the sharp peaks. The actual moisture contents lie close to the line of predicted moisture contents. A paired t-test showed no significant differences between predicted and actual soil moisture.

The three regression equations used to predict denitrification are given in Table 2 .

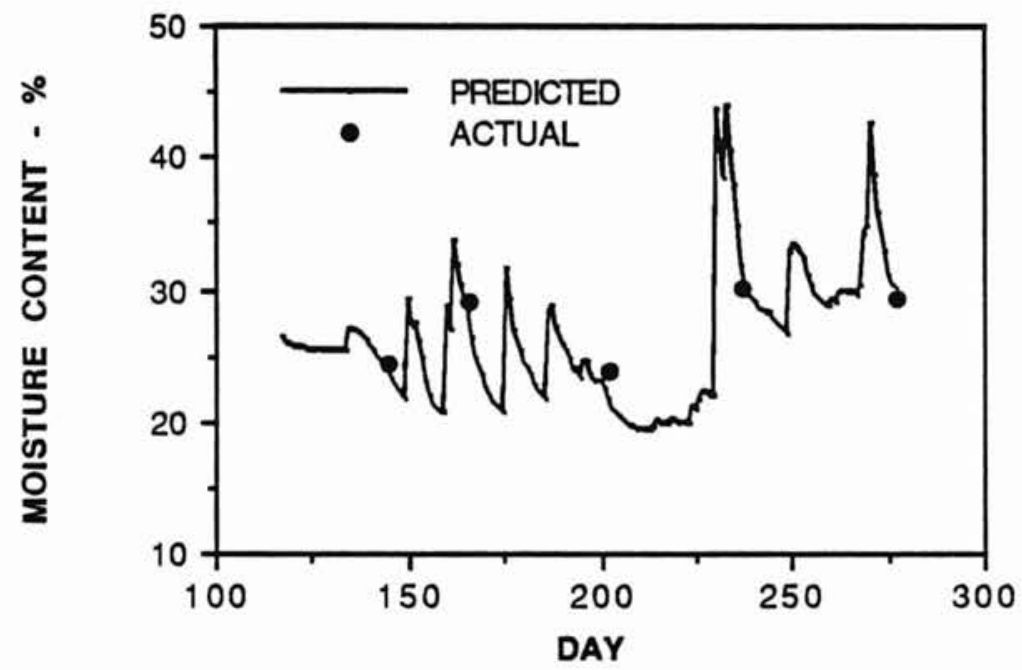

Figure 2. $\quad$ Predicted and actual moisture contents. 
Table 2. Regression equations used to predict denitrification.*

\begin{tabular}{|c|c|c|c|}
\hline & 1986 & 1987 & 1988 \\
\hline $\begin{array}{l}\text { Moisture Coefficient } \\
\text { Temperature Coefficient } \\
\text { Constant } \\
\text { R-squared }\end{array}$ & $\begin{array}{c}0.125 \\
0.081 \\
3.630 \\
0.62\end{array}$ & $\begin{array}{c}0.284 \\
0.108 \\
6.364 \\
0.56\end{array}$ & $\begin{array}{c}0.201 \\
0.095 \\
3.500 \\
0.52\end{array}$ \\
\hline
\end{tabular}

* Note that the equations predict the natural $\log$ of denitrification in $\mathrm{g} / \mathrm{h} / \mathrm{d}$ from moisture in \% v/v and temperature in ${ }^{\circ} \mathrm{C}$.

The moisture and temperature coefficients and constant values are higher in the fallow year (1987) than in the other two years. This is indicative of the flush of microbial activity which occurs under summerfallow where there is readily available substrate and no competition for moisture from growing plants. Figures 3 and 4 show predictions of denitrification in 1988 and 1987, respectively. In 1988 the predicted and actual values agree very well but in 1987 the first three denitrification measurements are underestimated by the model. This shows that the model with its inputs limited to moisture and temperature was unable to account fully for the flush of denitrifying activity in the fallow soil. Annual denitrification predictions for 1987 therefore underestimate the actual losses.

Annual denitrification losses for the landscape elements and the field averages are given in Table 3.

Table 3. Predicted annual denitrification losses from the landscape elements and field averages.*

\begin{tabular}{|c|c|c|c|}
\hline \multirow{2}{*}{$\begin{array}{c}\text { Landscape } \\
\text { Element }\end{array}$} & \multicolumn{3}{|c|}{---- Denitrification, kg/ha/yr --..-- } \\
\hline & 1986 & 1987 & 1988 \\
\hline $\mathrm{LL}$ & 3.5 & 44.2 & 10.9 \\
\hline CF & 2.3 & 22.8 & 5.6 \\
\hline DF & 2.5 & 41.0 & 15.1 \\
\hline $\mathrm{CB}$ & 1.2 & 7.6 & 5.1 \\
\hline LB & 1.5 & 9.9 & 4.8 \\
\hline LH & 1.2 & 5.6 & 3.6 \\
\hline DB & 1.6 & 15.7 & 4.8 \\
\hline CS & 1.3 & 8.6 & 5.2 \\
\hline DS & 1.3 & 9.7 & 2.6 \\
\hline Average & 1.8 & 17.6 & 5.9 \\
\hline
\end{tabular}

* Note that the elements are arranged so that the wettest elements are at the top and they become progressively drier towards the bottom. 


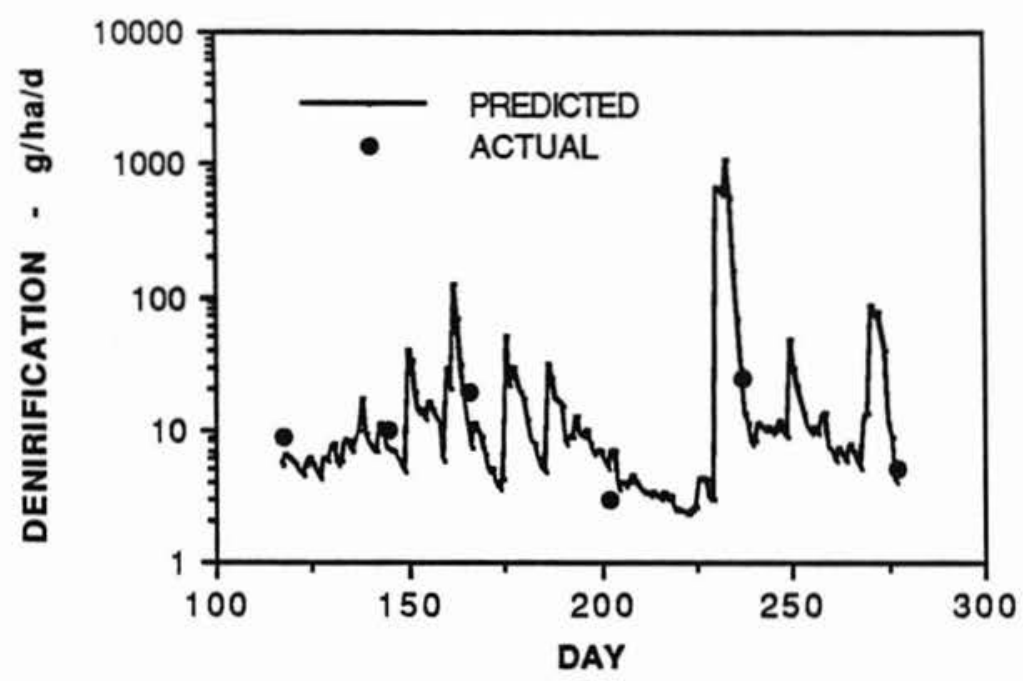

Figure 3. Predicted and actual denitrification in 1988.

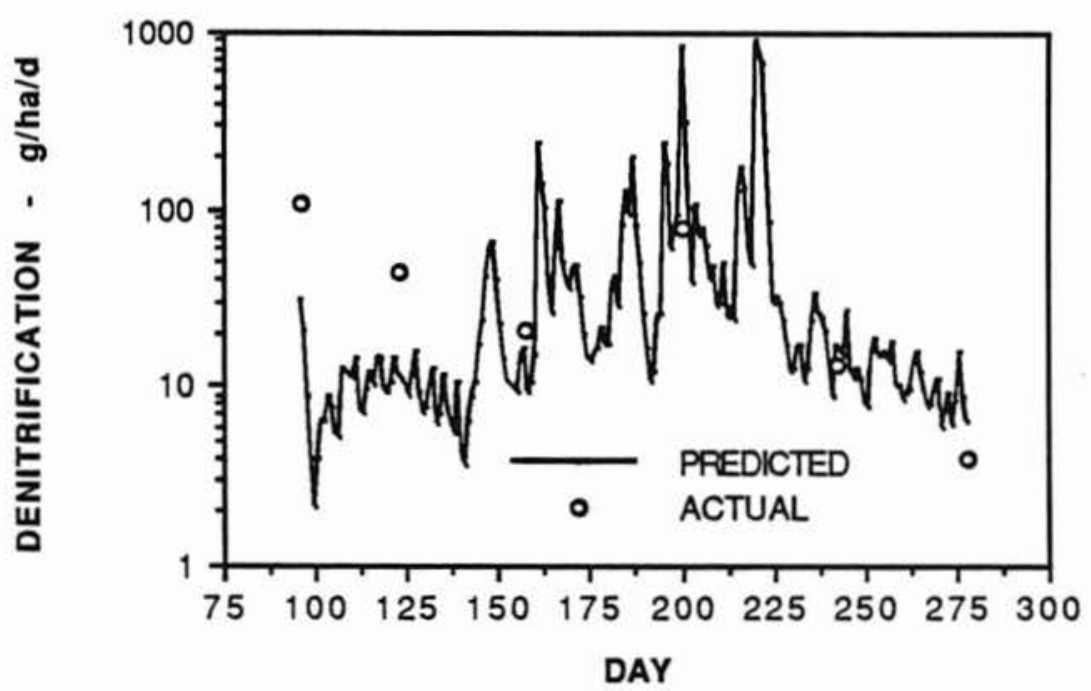

Figure 4. Predicted and actual denitrification in 1987, the fallow year. 
In 1986 denitrification ranged from a maximum of $3.5 \mathrm{~kg} / \mathrm{ha} / \mathrm{yr}$ on the low level to around $1 \mathrm{~kg} / \mathrm{ha} / \mathrm{yr}$ on the drier elements for a field average of $1.8 \mathrm{~kg} / \mathrm{ha} / \mathrm{yr}$. In 1987 , the fallow year, losses ranged from $44.2 \mathrm{~kg} / \mathrm{ha} / \mathrm{yr}$ on the low level unit to $5.6 \mathrm{~kg} / \mathrm{ha} / \mathrm{yr}$ on the high level unit for a field average of $17.6 \mathrm{~kg} / \mathrm{ha} / \mathrm{yr}$. The field average in 1988 was 5.9 $\mathrm{kg} / \mathrm{ha} / \mathrm{yr}$, ranging from $15.1 \mathrm{~kg} / \mathrm{ha} / \mathrm{yr}$ on the diverging footslope to $2.6 \mathrm{~kg} / \mathrm{ha} / \mathrm{yr}$ on the diverging shoulder.

Greater denitrification losses were observed from the low-lying and more concave elements than from the higher and more convex elements which have poorer water retention. Average denitrification losses of around $18 \mathrm{~kg} / \mathrm{ha}$ in the fallow year indicate that denitrification losses from fallow are significant in the nitrogen balance. Nitrogen losses due to denitrification in the cropped years were less significant but may gain in importance in wet years. The precipitation in 1986 and 1987 was below the long term average for the site.

\section{SUMMARY AND CONCLUSIONS}

The Versatile Soil Moisture Budget adequately predicted soil moisture content on a daily basis from soil and meteorological data. The predicted moistures were used with air temperature to predict denitrification. Predicted denitrification losses ranged from around $45 \mathrm{~kg} / \mathrm{ha} / \mathrm{yr}$ on the low level landscape element in the fallow year (1987) to around 1 $\mathrm{kg} / \mathrm{ha} / \mathrm{yr}$ on some of the drier elements in 1986 . Field averages were 2,18 and $6 \mathrm{~kg} / \mathrm{ha}$ for 1986, 1987 and 1988 respectively. Since the 1987 loss of $18 \mathrm{~kg} / \mathrm{ha}$ from the fallow soil was probably underestimated by the model it must be concluded that denitrification plays an important role in the nitrogen balance of fallow soils in the Black soil zone.

The curvature-based classification system allows hummocky terrain to be characterized in a meaningful manner. The classification also made it possible to obtain field averages suitable for use in economic analysis.

\section{ACKNOWLEDGEMENTS}

The authors gratefully acknowledge the financial support of NSERC, the Canadian Commonwealth Scholarship and Fellowship Plan and the University of Saskatchewan.

\section{REFERENCES}

AULAKH, M.S. 1983. Gaseous $\mathrm{N}$ losses from soils under various cropping and tillage systems. Ph.D thesis. University of Saskatchewan, Saskatoon, Sask.

BAIER, W. and G.W. ROBERTSON. 1965. Estimation of latent evaporation from simple weather observations. Can. J. Plant Sci. 45:276-284.

BAIER, W. and G.W. ROBERTSON. 1966. A new versatile soil moisture budget. Can. J. Plant Sci. 46:299-315

DE JONG, E. 1981. Soil aeration as affected by slope position and vegative cover. Soil Science 131:34-43.

DE JONG, R. 1988. Comparison of two soil-water models under semi-arid growing conditions. Can. J. Soil Sci. 68:17-27.

FIRESTONE, M.K. 1982. Biological denitrification. In F.J. Stevenson ed. Nitrogen in Agricultural Soils. Agronomy 22:289-326. Amer.Soc. of Agron., Madison, Wisc. 
KACHANOSKI, R.G., E. DE JONG and D.A. RENNIE. 1985. The effect of fall stubble cultivation on overwinter recharge and grain yield. Soils and Crops Workshop, February 1985, University of Saskatchewan, Saskatoon, Sask.

KIRKLAND, J.A. and E. DE JONG. 1988. Effects of soil management on denitrification. Soils and Crops Workshop, February 1988, University of Saskatchewan, Saskatoon, Sask.

KLUTE, A. 1986. Water retention: laboratory methods. In A. Klute ed. Methods of Soils Analysis: Part 1 - Physical and Mineralogical Methods. Second edition. Agronomy 9:635-662. Amer.Soc. of Agron., Madison, Wisc.

MACYK, T.M., S. PAWLUK and J.D. LINDSAY. 1978. Relief and microclimate as related to soil properties. Can. J. Soil Sci. 58:421-438.

PENNOCK, D.J., B.J. ZEBARTH and E. DE JONG. 1987. Landform classification and soil distribution in hummocky terrain, Saskatchewan, Canada. Geoderma 40:297315.

RUHE, R.V. 1960. Elements of the soil landscape. Trans $7^{\text {th }}$ Int. Congr. Soil Sci., Madison, Wisc., 4:165-170.

SCHWAB, G.L., R.K. FREVERT, T.W. EDMINSTER and K.K. BARNES. 1966. Soil and Water Conservation Engineering, Second edition. John Wiley and Sons, Inc., New York. 